\title{
Pengaruh Ekstrak Etanol Daun Kelor (Moringa Oleifera Lam.) Terhadap Apoptosis Sel Granulosa Pada Mencit (Mus Musculus) Model Endometriosis
}

\author{
Yusri Dwi Lestari ${ }^{1}$, Hendy Hendarto ${ }^{2}$, idjiati $^{3}$ \\ ${ }^{1}$ Mahasiswa Magister Ilmu Kesehatan Reproduksi, Fakultas Kedokteran, Universitas \\ Airlangga Surabaya \\ ${ }^{2}$ Departemen Obstetri dan Ginekologi, Fakultas Kedokteran, Universitas Airlangga, \\ RSUD Dr. Soetomo \\ ${ }^{3}$ Departemen Embriologi Veteriner, Fakultas Kedokteran Hewan, Universitas Airlangga \\ e-mail : ucchie.ay@gmail.com
}

\begin{abstract}
ABSTRAK
Endometriosis adalah suatu kondisi inflamasi kronis dan terdapat jaringan endometrium yang tumbuh diluar kavum uteri. Jaringan endometrium ini berkaitan dengan nyeri kronis, radang panggul, dan infertilitas yang sering diderita perempuan usia reproduksi. Apoptosis sel granulosa yang meningkat pada endometriosis menyebabkan folikel tidak dapat berkembang menjadi folikel de graf sehingga menyebabkan infertilitas. Daun kelor mengandung flavonoid yang dapat menghambat NFk $\beta$ kemudian menghambat apoptosis melalui jalur TNF- $\alpha$. Tujuan dari penelitian ini untuk membuktikan apoptosis sel granulosa pada mencit model endometriosis yang diberi ekstrak etanol daun kelor lebih rendah dari pada yang tidak diberi. Jenis penelitian ini true eksperimental dengan desain randomized post test only kontrol group design. Sampel 24 mencit betina yang dibagi 2 kelompok terdiri kelompok kontrol dan kelompok perlakuan. Kelompok kontrol dan perlakuan dijadikan endometriosis selama 14 hari, kemudian 14 hari berikutnya kelompok kontrol diberi plasebo (Na-CMC) dan kelompok perlakuan yang diterapi dengan ekstrak etanol daun kelor selama 14 hari dengan dosis 0,35 mg/gBB. Hari ke 29 mencit di terminasi dengan dislokasio os cervikalis dan diambil organ ovarium untuk dilakukan pemeriksaan imunohistokimia. Hasil penelitian di uji menggunakan U Mann Whitney didapatkan nilai signifikan 0,001, $p<0,005$. Kesimpulan dari penelitian ini adalah pemberian ekstrak etanol daun kelor dapat menekan jumlah apoptosis sel granulosa pada mencit model endometriosis.
\end{abstract}

Kata kunci : endometriosis, sel granulosa, daun kelor 


\begin{abstract}
Endometriosis is a chronic inflammation condition with the presence of endometrial tissue outside of cavum uteri. This endometrial tissue is related to the chronic pain, pelvic inflammatory disease, as well as infertility mostly in reproductive aged woman. Increased apoptosis of granulosa cells in endometriosis causes follicles to develop into de-graf folikel causing infertility. Moringa oleifera leaf has a flavonoid compound that affects the attenuation of NFkB and prevention of the apoptosis through TNF-a pathway. The aim of this study was to assess the effect of ethanol extract from Moringa oleiferaleaf to granulosa cell apoptosis in the endometriosis mice model. The design of this study is a true experimental with the randomized post test only control group design. Twenty four mice were divided into 2 groups, 1 control group and 1 treated group. For the first 14 days, each group were treated to be endometriosis, in the subsequent 14 days, the control group was treated with placebo (Na-CMC) and the treated group was administered by ethanol extract from Moringa oleifera leaf in a dose dependent manner of $0,35 \mathrm{mg} / \mathrm{g} \mathrm{BB}$. The 29th day of the mice was terminated with a cervical dislocation os and an ovarian organ was taken for immunohistochemistry. The results of the test using U Mann Whitney obtained significant value 0.001, $p<0.005$. The conclusion of this research is giving of leaf kelur ethanol extract can suppress the amount of granulosa cell apoptosis in mice of endometriosis model.
\end{abstract}

Keywords:, Endometriosis, Granulosa, Moringa oleifera 
Jurnal Biosains Pascasarjana Vol. 20 (2018) pp

(C) (2018) Sekolah Pascasarjana Universitas Airlangga, Indonesia

\section{PENDAHULUAN}

Endometriosis merupakan penyakit yang menyebabkan rasa sakit, dan kemudian dapat menyebabkan peradangan pada panggul, adhesi, nyeri kronis, dan infertilitas, dan dapat berkembang menjadi ganas sebesar $31 \%$ (Lee et al., 2015).

Tiga teori untuk menjelaskan penyebab endometriosis yaitu : Transplantasi ektopik jaringan endometrium oleh menstruasi retrograde atau oleh aliran limfatik dari rahim ke ovarium. Transformasi (metaplasia) dari epitel coelomic ke dalam jaringan endometrium, dan aktor biokimia endogen dapat menginduksi sel peritoneal yang tidak berdiferensiasi berkembang menjadi jaringan endometrium. Endometriosis ditemukan pada 70 - 90\% wanita dengan gejala nyeri panggul (Wang et al., 2014). Gejala khas meliputi nyeri pelvis, dismenore, dan infertilitas (Kennedy et al., 2005 ).

Mekanisme terjadinya apoptosis dapat terjadi melalui enzimatik jika dilihat dari aktifitas caspase. Apoptosis dapat terjadi melalui FAST ligand (FAST-L). Sel T sitotoksik dan NK sel untuk membunuh sel target dapat dengan menggunakan sitotoksin. Sitotoksin ini mengandung bahan yaitu perforin dan granzym, dengan adanya perforin maka membrane sel target akan mengalami proliferasi, melalui lubang tersebut akan diinjeksikan granzym yang kemudian akan mengaktifasi caspase secara bertahap. Caspase yang aktif akan mengaktivasi DNAse yang akhirnya akan merusak DNA (Goldsby et al, 2000).

Adanya peningkatan apoptosis pada penderita dengan endometriosis menyebabkan jumlah folikel berkembang dan oosit matang menjadi lebih sedikit (Hendarto, 2012).

Pengobatan yang dapat dilakukan untuk endometriosis meliputi kontrasepsi oral kombinasi, gestrinone, medroxyprogesterone acetate, dan agonis gonadotropin releasing hormone (aGnRHs). Penggunaan obat-obatan hormonal, selain tingkat keberhasilan yang tinggi dapat pula menyebabkan berbagai macam efek samping dan komplikasi (Kennedy et al., 2005).

Apoptosis adalah program kematian sel melaui mekanisme gen. Apoptosis dapat terjadi secara fisiologis maupun secara patologis.

Sinyal kematian mengaktifkan Bcl-2 pro-apoptosis (Bid dan Bax) sehingga menyebabkan Cytochrome $C$ keluar dari mitokondria. Cytochrome $C$ berikatan dengan Apaf-1 yang terikat pada caspase 9, yang kemudian mengaktifkan caspase 3 dan menyebabkan kematian sel (Hussein et al., 2003). Caspase meliputi caspase inisiator ( 8 dan 9) dan caspase efektor (3, 6 dan 7). Aktifasi dari caspase mampu membelah enzim dan protein yang penting untuk kelangsungan hidup sel. Komplek apoptosome merupakan kompleks multiprotein yang terdiri dari cytochrom $c$, Apaf-1, caspase-9 dan ATP. Pembentukannya dimulai dengan pelepasan sitokrom $c$ dari mitokondria ke dalam sitosol dimana ia mengikat Apaf-1, kemudian mengikat caspase 9, yang kemudian menyebabkan caspase 3 mengalami auto activation untuk terjadinya apoptosis. Caspase-3 kemudian membelah substrat targetnya untuk mempengaruhi perubahan yang terkait dengan apoptosis (Hussein et al., 2003).

Sel granulosa merupakan sel somatik yang berkaitan erat dengan folikulogenesis. Sel granulosa berfungsi 
Jurnal Biosains Pascasarjana Vol. 20 (2018) pp

(C) (2018) Sekolah Pascasarjana Universitas Airlangga, Indonesia

memproduksi growth factor dan steroid yang berinteraksi dengan oosit selama perkembangan folikel di ovarium. kejadian apoptosis pada sel granulosa memainkan peran penting dalam proses atresia folikel. (Inoue et al., 2011).

Daun kelor (Moringa oleifera Lam.) adalah salah satu tanaman tanaman berkhasiat obat. Daun kelor berpotensi meningkatkan status gizi, serta dapat mencegah dan menyembuhkan berbagai penyakit (Krisnadi, 2015). Daun kelor mengandung mineral, asam amino essensial, antioksidan seperti vitamin $\mathrm{C}$, vitamin E, flavonoid, tanin, dan masih banyak lainnya. Salah satu yang paling menonjol dari kandungan daun kelor adalah quercetine dan chaempherol yang merupakan grup flavonoid tinggi. Flavonoid ini yang berfungsi sebagai anti inflamasi yang mampu menghambat $\mathrm{Nfk} \beta$ yang merupakan suatu penanda adanya reaksi inflamasi pada endometriosis (Anjani et al., 2016).

\section{BAHAN DAN METODE}

Penelitian ini menggunakan jenis penelitian true eksperimental dan rancangan yang digunakan adalah randomized post test only control group design. Populasi penelitian ini adalah mencit (Mus musculus) galur Balb/c betina. Sampel yang digunakan sebanyak 24 ekor yang terbagi dalam 2 kelompok. Kriteria inklusi dalam penelitian ini adalah mencit (Mus musculus) sehat, berat badan 20-25 gram, tidak cacat, bulu bersih dan tidak rontok, tidak luka, sebelumnya tidak pernah digunakan untuk penelitian.

Penelitian ini menggunakan bahan berupa organ ovarium dari mencit model endometriosis, ekstrak daun kelor yang dibuat di UPT Materia Medica Batu Malang, jaringan endometrium dari pasien dengan tumor jinak uterus, siklosporin A (sandimmun), water fluid injection, Na CMC, ethynil estradiol, apoptek kit, phosphate buffered saline (PBS).

Pembuatan mencit model endometriosis dimulai dari: mencit diadaptasi selama 1 minggu, kemudian mencit disuntik siklosporin A 10 $\mathrm{mg} / \mathrm{kgBB}$ IM pada paha tikus pada hari ke 1. Jaringan endometrium disimpan di PBS, di washing $2 \mathrm{x}$ dan di sentrifuse 2500rpm, supernatant dibuang, ditambah PBS dan penicillin 200IU/ml dan streptomycin $200 \mu \mathrm{g} / \mathrm{ml}$. Menggunakan spuit $3 \mathrm{ml}$ untuk mengambil jaringan basah endometrium. Penyuntikan jaringan endometrium dilakukan secara intra peritoneal sebanyak $0,1 \mathrm{ml} /$ mencit. Penyuntikan estrogen (ethynil estradiol) secara IM pada femur pada hari 1 dan 5 sebanyak $0,1 \mathrm{ml}$ menggunakan spuit $1 \mathrm{cc}$ di paha mencit. Kemudian mencit dilakukan perawatan dengan pemberian makan dan minum seperti biasa sampai hari ke 14 mencit telah menjadi model endometriosis.

Daun kelor melalui proses ekstraksi menggunakan metode maserasi dengan pelarut etanol 96\%. Daun kelor yang digunakan didapatkan pohon kelor dengan usia pohon yang sama (3 tahun) dan dari kebun yang sama. Daun kelor digrinder hingga berbentuk bubuk, dimasukkan ke dalam Erlenmeyer, kemudian ditambahkan etanol 96\%, dilarutkan dengan dikocok selama 2-3 jam. Selanjutnya, ditutup dengan alumunium foil.

Setelah dilakukan penyaringan dan didapatkan filtratnya kemudian diuapkan untuk memisahkan ekstrak dengan pelarutnya dengan rotary evaporator sampai didapatkan hasil ekstrak daun kelor yang bebas dari etanol (pelarut). 
Jurnal Biosains Pascasarjana Vol. 20 (2018) pp

(C) (2018) Sekolah Pascasarjana Universitas Airlangga, Indonesia

Perhitungan dosis ekstrak berdasarkan penelitian sebelumnya yaitu penelitian yang dilakukan pada tikus dengan dosis sebesar $250 \mathrm{mg} / \mathrm{kg}$ BB. Dosis tersebut dikonversi ke dosis mencit berdasarkan tabel konversi Kusumawati (2004), kemudian melalui proses perhitungan dan didapatkan dosis sebesar $0,35 \mathrm{mg} / \mathrm{g} \quad$ BB. Ekstrak disuspensi menggunakan larutan $\mathrm{Na}$ CMC 0,5\% agar larut dalam air dan diberikan peroral menggunakan sonde lambung. Terapi dengan ekstrak etanol daun kelor diberikan sebelum mencit diberi makan di pagi hari agar seluruh ekstrak dapat diabsorbsi oleh mencit, terapi ini dilakukan selama 14 hari.

Penelitian ini dilakukan di kandang hewan coba dan Laboratorium Patologi Veteriner Fakultas Kedokteran Hewan Universitas Airlangga pada bulan Maret 2018 sampai dengan bulan Mei 2018.

Pada hari ke 29 mencit dikorbankan dengan cara dislokasi os cervikalis, kemudian dilakukan pembedahan untuk mengambil ovariumnya. Setelah selesai, mencit kemudian dikuburkan.

\section{HASIL DAN DISKUSI}

Jumlah apoptosis sel granulosa diukur dengan imunohistokimia. Data dari setiap sampel dinilai secara semikuantitatif menggunakan metode Remmele yang sudah dimodifikasi (Novak et al., 2007), dimana Indeks skala Remmele (Immuno Reactive Score/IRS) merupakan hasil perkalian antara skor persentase sel immunoreaktif dengan skor intensitas warna pada sel immunoreaktif. Kemudian hasilnya dilakukan analisis statistik untuk membuktikan bahwa jumlah apoptosis sel granulosa mencit model endometriosis yang diberi ekstrak etanol daun kelor (Moringa oleifera) dengan dosis $0,35 \mathrm{mg} / \mathrm{g}$ BB lebih rendah dibandingkan yang tidak diberi.
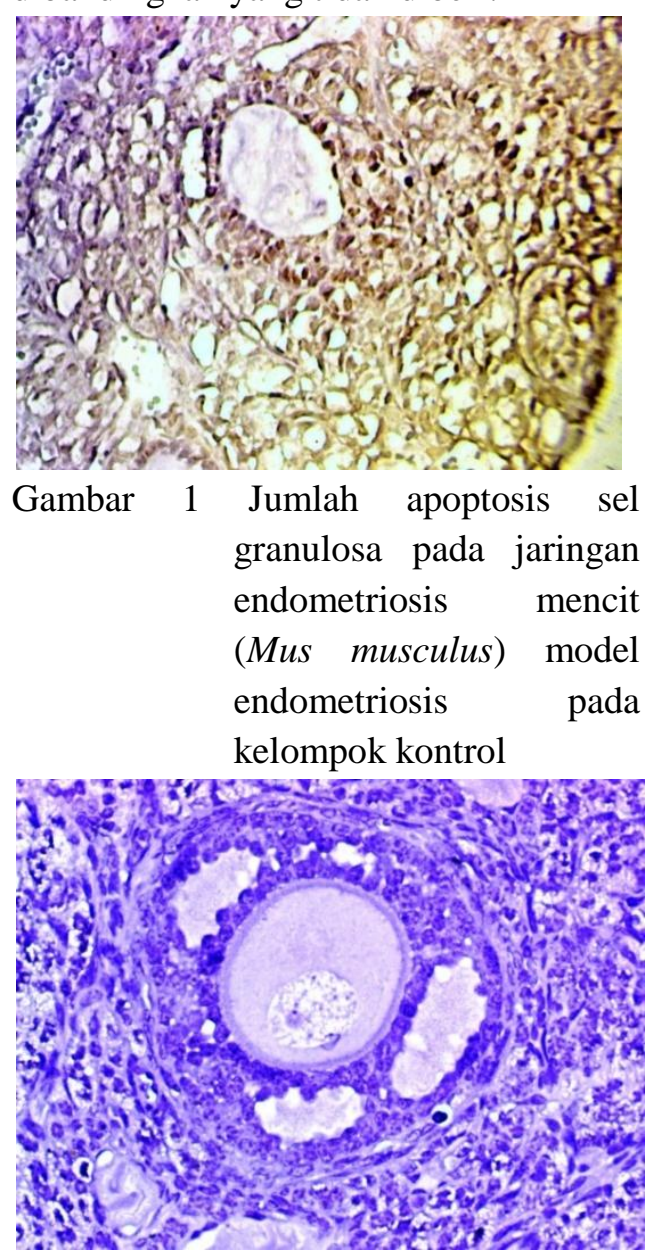

Gambar 1 Jumlah apoptosis sel granulosa pada jaringan endometriosis mencit (Mus musculus) model endometriosis pada kelompok yang diterapi ekstrak etanol daun kelor.

Tabel 1: Rerata dan simpangan baku jumlah apoptosis sel granulosa

Rerata dan simpangan baku jumlah apoptosis sel granulosa

\begin{tabular}{|c|c|c|}
\hline & K1 & $\mathrm{K} 2$ \\
\hline $\begin{array}{l}\text { Apoptosis sel } \\
\text { granulosa }\end{array}$ & $\begin{array}{c}0,63 \\
\pm 0,36\end{array}$ & $\begin{array}{c}0,20 \\
\pm 0,12\end{array}$ \\
\hline
\end{tabular}

Keterangan :

K1 : Kelompok kontrol

K2 : Kelompok perlakuan 
Jurnal Biosains Pascasarjana Vol. 20 (2018) pp

(C) (2018) Sekolah Pascasarjana Universitas Airlangga, Indonesia

Tabel 1 menunjukkan rerata dan simpangan baku jumlah apoptosis sel granulosa pada mencit model endometriosis kelompok kontrol dan kelompok yang mendapat terapi yang menunjukkan adanya penurunan apoptosis sel granulosa pada kelompok yang diterapi.

uji Shapiro Wilk digunakan untuk analisis statistik untuk normalitas data karena sampel kurang dari 50 . Berdasarkan hasil uji Shapiro Wilk, asumsi normalitas data tidak terpenuhi karena nilai kelompok kontrol menunjukkan hasil 0,03 , sehingga $\mathrm{p}<0,05$ yang berarti distribusi data tidak normal. Asumsi selanjutnya adalah homogenitas varian dengan uji Levene didapatkan hasil 0,13 sehingga lebih besar dari $0,05(\mathrm{p}>0,05)$ yang berarti homogenitas varian data terpenuhi. Karena normalitas data tidak terpenuhi, maka untuk membandingkan nilai dua kelompok digunakan uji $U$ MannWhitney dengan hasil signifikan yang sebesar 0,001, sehingga $\mathrm{p}<0,05$. Kesimpulan dari penelitian ini adalah terdapat perbedaan yang signifikan antara apoptosis sel granulosa pada kelompok kontrol dan kelompok perlakuan.

\section{DISKUSI DAN PEMBAHASAN}

Sel granulosa merupakan sel somatik yang berkaitan erat dengan folikulogenesis. Sel granulosa berfungsi memproduksi growth factor dan steroid yang berinteraksi dengan oosit selama perkembangan folikel di ovarium. kejadian apoptosis pada sel granulosa memainkan peran penting dalam proses atresia folikel. (Inoue et al., 2011).

Peningkatan reaksi radang di peritoneum pada penderita endometriosis berpengaruh pada folikel ovarium yang menyebabkan terjadinya proses apoptosis sel granulosa yang patologis sehingga folikel tidak dapat berkembang dan menyebabkan infertilitas, sejalan dengan penelitian Nakahara (1998) yang menjelaskan proses apoptosis patologis akan menyebabkan penurunan kesuburan dari ovarium sehingga dapat menyebabkan infertilitas.

Tinggi rendahnya apoptosis sel granulosa berkaitan dengan perkembangan folikel menjadi folikel de graff. Semakin tinggi jumlah apoptosis maka folikel akan mengalami atresia dan tidak berkembang menjadi folikel matang mengakibatkan tidak terjadinya ovulasi. Tidak terjadinya ovulasi menyebabkan terjadinya infertilitas.

Mencit betina digunakan sebagai hewan coba model endometriosis dalam penelitian ini karena memiliki homologi anatomi dengan manusia. Mencit dibagi menjadi 2 kelompok. Pembuatan hewan model endometriosis selama 14 hari, kemudian satu kelompok diterapi dengan ekstrak etanol daun kelor dosis $0,35 \mathrm{mg} / \mathrm{g} \mathrm{BB} /$ hari selama 14 hari dan kelompok yang lain sebagai kelompok kontrol.

Daun kelor memiliki kandungan flavonoid yang tinggi, salah satu yang paling menonjol adalah quercetine yang berfungsi sebagai antiinflamasi. Penelitian Anjani dkk (2016) quercetine berfungsi sebagai anti inflamasi yang mampu menghambat $\mathrm{NfkB}$ yang merupakan suatu penanda adanya reaksi inflamasi pada endometriosis. Penelitian wihastuti dkk (2007) membuktikan bahwa. Kandungan antiinflamasi yang tinggi pada daun kelor juga mampu menghambat TNF- $\alpha$. Penghambatan pada NFkB dan TNF- $\alpha$ menyebabkan tidak terbentuknya ikatan antara TNF- $\alpha$ 
Jurnal Biosains Pascasarjana Vol. 20 (2018) pp

(C) (2018) Sekolah Pascasarjana Universitas Airlangga, Indonesia

dan TNF- $\alpha$ reseptor yang merupakan reseptor kematian sel menjadi terhambat.

Pemeriksaan jumlah apoptosis sel granulosa menggunakan imunohistokimia dilakukan setelah mencit dikorbankan pada hari ke-29. Berdasarkan hasil analisa statistik $U$ Mann Whitney menunjukkan perbedaan bermakna antara kelompok perlakuan dan kelompok kontrol dengan nilai $\mathrm{p}<$ 0,05 .

\section{KESIMPULAN DAN SARAN}

Apoptosis sel granulosa pada mencit (Mus musculus) model endometriosis kelompok perlakuan dengan ekstrak etanol daun kelor (Moringa oleifera Lam.) lebih rendah dibandingkan dengan kelompok kontrol.

Dapat dilakukan penelitian untuk melihat ekspresi caspase untuk melihat jalur sinyal apoptosis telah berlangsung.

\section{DAFTAR PUSTAKA}

Andjani, N., Sujuti, H., and Winarsih, S. 2016.'Efek ekstrak etanol daun kelor (moringa oleifera) terhadap nuclear factor kappa beta (Nf-kB) aktif dan apoptosis cell line kanker mcf-7'. Majalah Kesehatan FKUB. 3 (4): 204-212.

Hendarto, H. 2012. 'Pathomechanism of infertility in endometriosis. in endometriosis-basic concept and current research trends'.Intech : 343-353.

Hussein, MR., Haemel, AK., and Wood, GS. 2003.'Apoptosis and melanoma:molecular mechanisms'. J Pathol. 199 : 275 -288 .

Inoue., Noriyuki. 2011. 'Role of celldeath ligand-receptor system of granulosa cells in selective follicular atresia in porcine ovary'. J Reprod Dev. 57(2) : 169-175.

Kennedy, S., Bergqvist, A., Chapron, C., D'Hooghe, T., and Dunselman, G.2005. 'ESHRE guideline for the diagnosis and treatment of endometriosis'. HumReprod. 20: 2698-2704.

Krisnadi, A. 2015. Kelor Super Nutrisi.. Pusat Informasi Dan Pengembangan Tanaman Kelor Indonesia : Blora.

Goldsby, RA., Kindt, TJ., and Osborne, BA. 2000. Kuby Immunology $4^{\text {th }}$ edition. W.H Freeman and Company : New York.

Lee, WL., Chang, WH., Wang, KC., Guo, CY., Chou, YJ., and Huang, N. 2015.'Therisk of epithelial ovarian cancer of women with endometriosis may bevaried greatly if diagnostic criteria are different'.Medicine.94: e 1633.

Nakahara, K., Saito,H., Saito, T., Ito,M., Ohta, N., Takahashi,T., and Hiroi,M. 1998. 'Ovarian fecundity in patients with endometriosis can be estimated by the incidence of apoptotic bodies'. Fertil Steril.69(5):931-5.

Wang, KC., Chang, WH., Lee, WL., Huang, N., Huang, HY., and Yen, MS. 2014. 'Anincreased risk of epithelial ovarian cancer in taiwanese women with a new surgico pathological diagnosis of endometriosis'. BMC Cancer. 14:831.

Wihastuti, T.A., Sargowo, D., and Rohman, M. 2007. 'The Effect of 
Jurnal Biosains Pascasarjana Vol. 20 (2018) pp

(C) (2018) Sekolah Pascasarjana Universitas Airlangga, Indonesia

Moringa Oleifera Leaf Extract in

Inhibition of NFKB Activation,

TNF- $\alpha$ and ICAM-1 Expression

in Oxidized LDL treated

HUVECS'. J. Cardiol. Indonesia.

28:181-188. 